\title{
Transparency, Integration, and the Cost of International Real Estate Investments
}

\author{
Piet M. A. Eichholtz • Nils Gugler • Nils Kok
}

Published online: 27 April 2010

(C) The Author(s) 2010. This article is published with open access at Springerlink.com

\begin{abstract}
This paper investigates the importance of market institutions for the performance of international property investors during the 1996-2007 period. The results show that international property companies underperform local property companies in the early years of the sample period. This underperformance is driven by the political environment, the level of economic integration, and the transparency of the real estate market in target countries. The underperformance of internationals disappears in the later years of the sample period, and so does the significance of the aforementioned factors in explaining performance differences among international companies. These findings suggest that the increased transparency of the global real estate industry has leveled the playing field for foreign property investors.
\end{abstract}

Keywords Real estate $\cdot$ Transparency $\cdot$ Political risk $\cdot$ Investments $\cdot$ International

\section{Introduction}

The path-breaking studies of La Porta et al. (1998, 2000a, 2002) have clearly demonstrated the importance of the legal institutions underpinning international capital markets for international investments. Political respect for property rights, a reliable corporate governance framework, and legal protection of outside shareholders have all been shown to be beneficial for the development of financial markets and the valuation of firms. Indeed, Dahlquist et al. (2003) demonstrate that

We thank seminar participants at the 2008 REIT symposium at DePaul University, Chicago, as well as Joseph Ooij and Andy Naranjo for their helpful comments.

P. M. A. Eichholtz $\cdot$ N. Gugler • N. Kok $(\bowtie)$

Maastricht University, PO Box 616, 6200 MD Maastricht, the Netherlands

e-mail:n.kok@maastrichtuniversity.nl

P. M. A. Eichholtz

e-mail: p.eichholtz@maastrichtuniversity.nl

N. Gugler

e-mail: n.gugler@alumni.maastrichtuniversity.nl 
the home bias in equity portfolio holdings by investors is, at least partly, the result of corporate governance factors in foreign markets. Yet for real estate investments, the effect of institutional differences across national markets on the shape and performance of international investment portfolios has not yet been documented. This is surprising, since the quintessential characteristic of real estate, its immobility, would make it especially vulnerable to weak institutional settings. This may be part of the reason why real estate investment, until quite recently, was mainly a local affair.

However, real estate investment has become increasingly global over the past decade. This globalization is reflected in global investment volumes. For example, over the 5 year period to 2006, cross-border investments have tripled to a level of US\$ 116 billion, which amounts to $20 \%$ of all property investment worldwide (Hobbs et al. 2007). The highest fraction of cross-border activity takes place within Europe, where cross-border investment was US\$ 84 billion in 2006. European investors mainly focus on cross-border investment within their continent, while investors from America and Asia-Pacific are increasingly active across regions. Among cross-border investors, the number of listed property companies following a global expansion strategy is increasing. In addition, those listed property companies that are already operating internationally are often further broadening their investment strategies.

Arguably, the increase in international real estate capital flows could foster increasing demand for stronger institutions across global real estate markets. Indeed, the real estate industry has experienced fundamental changes over the past decade. The most recently published Real Estate Transparency Index of Jones Lang LaSalle shows that real estate transparency around the world continues to improve. Nearly one-half of the markets surveyed demonstrate an improvement in their composite transparency scores between 2006 and 2008. The largest improvements were made in previously unstable and intransparent countries like Romania, Ukraine, and Russia (JLL 2008). Further sources of increased real estate market transparency are the internationalization of real estate service providers, the rise of common investment vehicles (Eichholtz and Kok 2007), and more sophisticated and mature performance benchmarks, like the indices of the Investment Property Databank (IPD).

At the same time, political barriers have been gradually reduced. The liberalization of capital markets in many countries has increased the economic and political pressure to create financial instruments acceptable to foreign investors. These pressures give rise to several forms of functional convergence of markets (La Porta et al. 2000b). This means that foreigners are - at least in those converging real estate markets - more likely to face investment conditions similar to locals.

It is likely that the increased transparency reduces the information asymmetry problems that international real estate investors faced hitherto. Previous evidence on the market implications of these problems documents that internationally diversified property companies underperform local property companies by approximately three percent per year, during the 1984-1995 period (Eichholtz et al. 2001). Reducing the information disadvantages of international investors could imply that internationally operating property companies have improved their performance compared to those companies that operate locally.

This paper studies the performance and performance drivers of internationally operating property companies relative to their local counterparts during the 1996-2007 period. We find that international property companies underperform both pure-play 
local property companies and a synthetic benchmark with similar country weights in the early years of this period. The underperformance is driven by the political environment, the level of economic integration, and the transparency of target countries' real estate markets. The internationals' underperformance disappears in the later years of the sample period, and so does the significance of the aforementioned factors in explaining performance differences among international companies. We explain these findings by the increased global transparency of the real estate industry as a whole, which has leveled the playing field for foreign property investors.

The remainder of this paper is structured as follows. Section Literature Review: Cross-border Real Estate Investments reviews the literature regarding motives and obstacles to cross-border property investments. Section Data provides information on the dataset and descriptive statistics. Section The Performance of Internationals versus Locals maps the performance difference between internationals and locally investing property companies, and Section Performance Drivers investigates the drivers of the performance differences. The last section concludes the paper and provides implications and limitations.

\section{Literature Review: Cross-border Real Estate Investments}

Over the past two decades, a wide range of studies has addressed the diversification potential of international real estate investments. An excellent review of that literature can be found in Worzala and Sirmans (2003a, b). Overall, the empirical evidence indicates that there are significant diversification benefits in global property investments. Cross-country correlations are found to be low, especially among markets from different continents (Eichholtz 1996; Eichholtz et al. 1998), although the results depend on the treatment of currency risk and the time period studied.

Studies of international diversification effects within mixed-asset portfolios, like Quan and Titman (1997) and Hoesli et al. (2004) provide evidence that there are gains from international diversification in direct property investments. Liu and Mei (1998) and Conover et al. (2002) confirm these results for indirect property investments.

Diversification benefits have also been documented when the analysis is limited to the effects within real estate portfolios. Worzala and Sirmans (2003b) and Eichholtz $(1996,1997)$ find strong benefits of international diversification. Several studies have investigated whether country-specific, continental, or worldwide factors drive international real estate returns. Eichholtz et al. (1998) report evidence of continental factors in Europe and in North America, while there is no dominant continental factor in the Asia-Pacific region. The authors therefore conclude that European and American real estate investors should diversify across continents. Ling and Naranjo (2002) find evidence of a worldwide factor in global real estate returns. However, even after controlling for worldwide systematic risk, country-specific factors are still highly significant, suggesting international diversification benefits.

There are some exceptions to the consensus on the benefits of international diversification of property investments. Ziobrowski and Curcio (1991) do not detect significant diversification gains, and a study by Goetzmann and Wachter (1995) shows that the 1992 downturn in rents and property values in the U.S. was experienced by $90 \%$ of the international property markets. 
The benefits of international real estate investments notwithstanding, there are also costs and risks involved. However, while several studies investigate the risks of venturing in real estate markets overseas (Geurts and Jaffe 1996; Liao and Mei 1999), studies that address how these risks and costs affect the returns of foreign real estate investments are scant. Eichholtz et al. (2001) compare the performance of 18 internationally operating property companies ("internationals") with the performance of property companies focusing on their local market ("locals") during the 19841995 period. The results show that internationals underperform locals by $2.7 \%$ per year (on a risk-adjusted basis) and that this underperformance is consistent over time. The authors show that the results are not driven by transaction costs, leverage, or currency effects, and attribute the performance difference to informational disadvantages. However, they do not formally address this hypothesis. The paper also shows that international property companies can partly overcome informational disadvantages as they grow in size.

A more recent study by Edelstein et al. (2009) shows that the risk premia for listed property shares are partly determined by the quality of a country's legal system and corporate governance environment, after controlling for country-specific macro variables and firm-level characteristics like size and capital structure. The notion that information costs are a main performance driver of internationally diversified property companies is supported by surveys among institutional investors. These surveys often identify the lack of local knowledge as an impediment to cross-border investments, as well as other obstacles, such as political risk, currency risk, transaction costs, and liquidity issues (Dhar and Goetzmann 2006; Newell and Worzala 1995, 1997; Worzala 1994). In addition, going international is associated with a loss of corporate focus that could likewise have an impact on the performance of international property companies (Boer et al. 2005; Capozza and Seguin 1999). We will discuss these issues in the remainder of this section.

A critical issue concerning cross-border property investments is foreign investors' lack of local expertise and the limited access to local market information. This issue is not specific to the real estate sector, and is well-discussed in the more general finance literature (Adler and Dumas 1975; Armstrong and Riddick 1998). As private real estate markets are unlikely to be as informationally efficient as public equity markets, prices do not necessarily and instantaneously reflect all available and relevant information. Local investors, who have superior information, can therefore have a competitive advantage. At the same time, given that foreign investors are often less well informed, with less local expertise, they will likely pay too much for their assets and buy more lemons (Eichholtz et al. 2001). This leads to returns that are likely to be lower than those of their local counterparts. One potential solution to these informational disadvantages is to create a stronger local presence. Eichholtz et al. (2001) find that the underperformance of internationals is reduced for larger firms. They conclude that an increase in asset base gives foreign investors the possibility to overcome informational disadvantages by realizing economies of scale in the generation of information.

Regarding political uncertainty, there is consensus in the literature that internationally operating firms face greater risk than local firms due to increased political risk exposure. For the real estate sector, Liao and Mei (1999) document a positive relationship between property returns and a country's economic efficiency and economic freedom. Other discriminatory factors range from taxation differences 
(Eichholtz and Kok 2007), which may also be found in North-American and European markets, to planning and building codes that are inconsistently applied to foreigners. The most extreme risk is the outright expropriation of property by the government, with no or inadequate compensation. According to a real estate transparency study by Jones Lang LaSalle (2008), this risk is for example present in some more exotic markets, like Venezuela and Panama.

Benefits and return opportunities following international diversification are likely to exist. However, these benefits may as well be obtained by end-investors through investing in foreign property companies that have a local focus. Intermediate investors, like listed property companies, should therefore only invest abroad if they are able to operate in foreign markets at least as efficiently as locals.

Transaction costs, though varying across countries, are not relevant for the property company's decision to go abroad. Local companies are likely to face similar fees and consequently there is no way of escaping these costs for an end-investor who wants to gain exposure to an international real estate market. Currency risk will also be unable to explain consistent differences in the risk-adjusted returns of internationals and locals, as currency movements will similarly enhance or diminish their returns from a foreign investor's point of view.

Thus, additional problems that property companies are likely to face in operating abroad are mainly: higher political risks, increased liquidity problems, informational disadvantages, and loss of corporate focus. These factors may consistently diminish the returns to foreign investors.

\section{Data}

To investigate the performance of internationally diversified property companies, we use a sample of 848 property companies from 36 countries around the globe, from 1996 through 2007. The sample is obtained by a combination of two data sources. First, we use the Global Property Research (GPR) Handbook Database. GPR has collected information on more than 700 listed property companies in all continents on a monthly basis since 1984. The database is survivorship-bias free. We include both property investment companies and hybrids between investors and developers. Second, we use the Worldscope database, from which we select all companies either classified as "real estate holding and development company" or "real estate investment trust" (REIT). Companies are only included in the sample if property investing is their principal activity. In the merged dataset, companies for which no financial data is available are excluded, as well as open-ended real estate funds, as the performance of the latter is artificially smooth.

The remaining companies are classified as "internationals" or "locals". In years in which property companies invest at least $25 \%$ of their portfolio outside the home market, companies are considered to be international. ${ }^{1}$ We exclude international

\footnotetext{
${ }^{1}$ The home market is the country where the company has its main stock market listing unless it has more than $75 \%$ invested in an other market, which is then considered to be the home market. The cut-off point is similar to Eichholtz et al. (2001) to ensure comparability of the results. Although the cut-off point is somewhat arbitrarily chosen, using different cut-off points does not significantly change the results.
} 
Hong Kong property companies investing in mainland China, as we consider Hong Kong and China to be a single national market. This leads to a sample of 67 property companies that are considered as international for at least 1 year and 465 property companies that can be classified as locals. ${ }^{2}$ Our sample of internationals is substantially larger than the sample of Eichholtz et al. (2001), who use a sample of 18 internationals out of a total universe of 360 property companies (in 1996).

Table 1 provides an overview of the international property companies, including sample statistics and basic information on portfolio composition and size. About half of the internationals are European companies, and within Europe, most internationals originate from the Netherlands and the United Kingdom, which both have a long tradition of investing internationally. This may be due to the large amount of institutional money on relatively small home markets. Asian property companies make up a substantial part of the sample as well, with internationals mainly based in Singapore and Hong Kong. North American companies constitute only about $12 \%$ of the internationals sample and most of the international property companies originate from Canada rather than the United States. Columns 3, 4, 5, and 6 of Table 1 provide average returns, standard deviations, the first month for which an observation is available and the total number of months for which we have data. Asian property companies have on average the highest returns, but these come with a high volatility.

Columns 7 through 11 of Table 1 provide information on the portfolio composition of the internationals as of December 31,2007, or the last year when the company was considered to be an international. The data shows that most companies are mainly active on their own continent, and focus on a limited number of markets. The most diversified, in terms of countries covered, are the European internationals with investments in on average 3.91 countries. Prominent examples of geographically diversified firms in Europe are the French shopping center investor Klepierre, Germany's IVG Immobilien, and Wereldhave of the Netherlands. The least diversified internationals originate from North America, which are mainly Canadian property companies operating in the United States. An exception is the US-based Shurgard Storage Centers, a self-storage REIT operating in eight countries across North America and Europe. ${ }^{3}$

While the European and the North American companies tend to invest within their continents, Asian and especially Australian property companies are active across regions. Examples of Australian listed property trusts with an international focus are the Macquarie Countrywide Trust and the Centro Retail Trust, both very active in the United States. The most diversified company in the sample is the Singaporean Ascott Group Limited, a serviced residence owner and operator with properties in Asia-Pacific, Europe, and the Gulf region.

Finally, Table 1 provides information on market capitalization of internationally oriented property companies. On average, the market capitalization of internationals is over US\$2 billion, with the distribution skewed to the right. The firms with the

\footnotetext{
${ }^{2}$ Property companies can be classified as local or international interchangeably during the sample period, depending on the country allocation in a given year.

${ }^{3}$ Shurgard Storage Centers was acquired in August 2006 and is now part of the U.S. company Public Storage.
} 
highest market capitalization originate from the Australian continent. This result is mostly driven by the Westfield Group, an Australian shopping center operator, with a market capitalization of more than US\$ 27 billion.

\section{The Performance of Internationals Versus Locals}

Our empirical setup initially follows the method proposed by Eichholtz et al. (2001). We first construct a value-weighted index solely consisting of international property companies - the "internationals" index - and a value-weighted index solely consisting of local property companies - the "locals" index. Then, we construct customized benchmarks for each property company that is classified as international. To set up these benchmarks, value-weighted return indices are calculated for each country, only consisting of firms that focus on the local market. These country indices are then combined to reflect the country allocation of each international property company. ${ }^{4}$ The benchmark is rebalanced yearly, to reflect changes in the geographical asset allocation of the international. An international's customized benchmark contains local property companies only and has the same combined country allocation as the particular international property company.

Comparing the internationals index with the locals index compares two investment portfolios that not only differ in investment strategy, but also in terms of geographical asset allocation. However, the customized benchmark compares two investment portfolios that only differ in the way how they are set up: through direct foreign property investments by an international property company or through indirect foreign property investments in locally operating property companies. These represent the two alternative methods for an end-investor to build up international real estate exposure.

To assess the performance of the internationals relative to their benchmarks, monthly performance data for all 848 property companies is retrieved from Datastream for the period from January 1996 through December 2007. All indices are retrieved in U.S. dollars to ensure comparability. The total return indices of the local property companies are then combined into a value-weighted locals index. Second, the total return indices of local companies are the basis for a set of country indices. Companies are only included in a country index in years where they actually meet the criteria to be considered as locals in that country. The weights of the locals in the country indices are determined by their respective market capitalization:

$$
C I_{i, t}=C I_{i, t-1} *\left[1+\frac{\left(\sum_{j=0}^{j=n t}\left(R_{j, t} * A P_{j, t-1}\right)\right)}{\left(\sum_{j=0}^{j=n t} C A P_{j, t-1}\right)}\right]
$$

\footnotetext{
${ }^{4}$ The country allocations are derived from asset or sales data in the annual reports, whereby the former was preferred over latter. While sales are a summary figure of what happened during the year, assets provide a snapshot of the company at the end of the fiscal year. The country allocations derived from assets are used for the half year periods before and after the fiscal year end date. Country allocations derived from sales apply to the one year period before the fiscal year end date.
} 


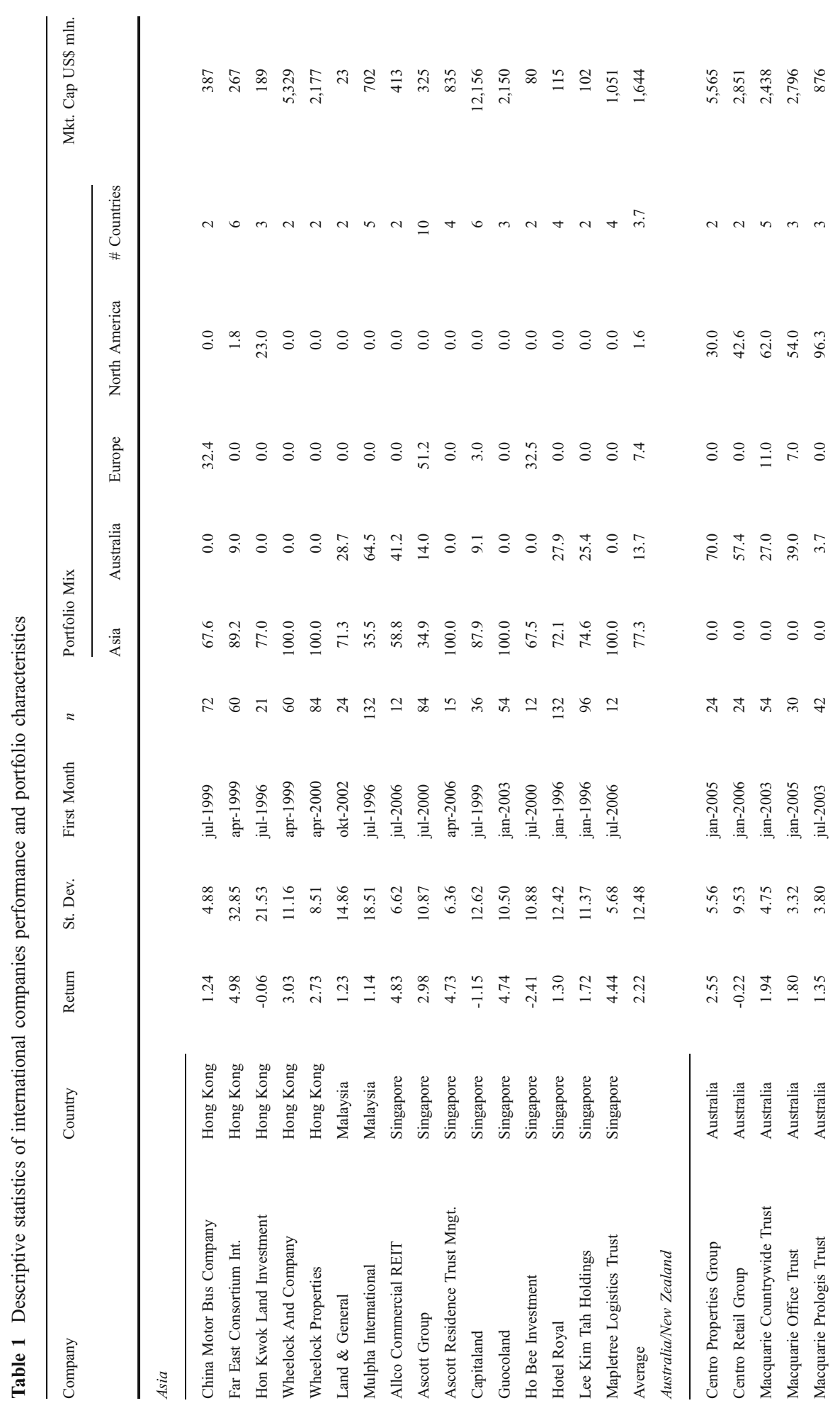




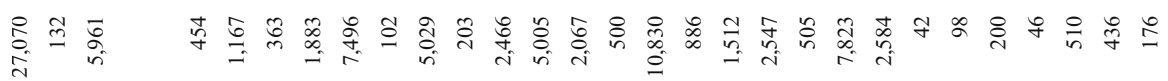

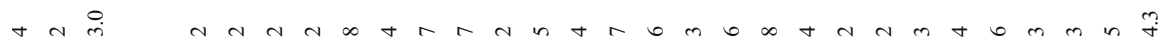

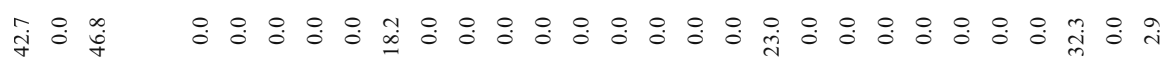

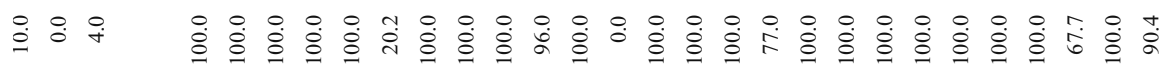

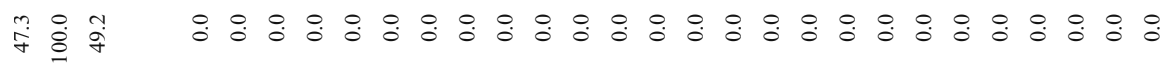

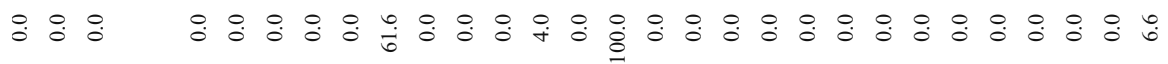

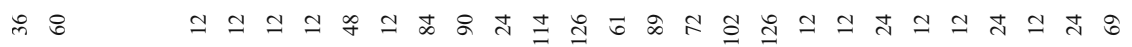

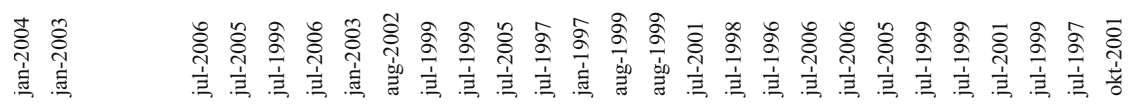

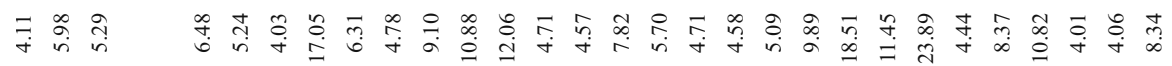

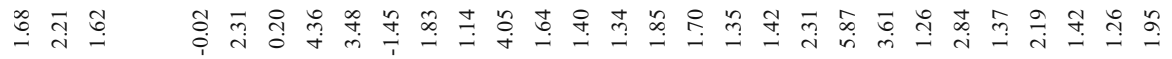

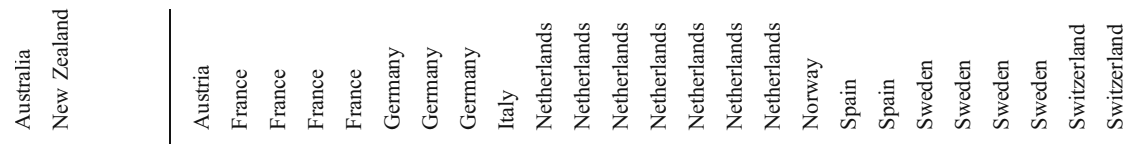

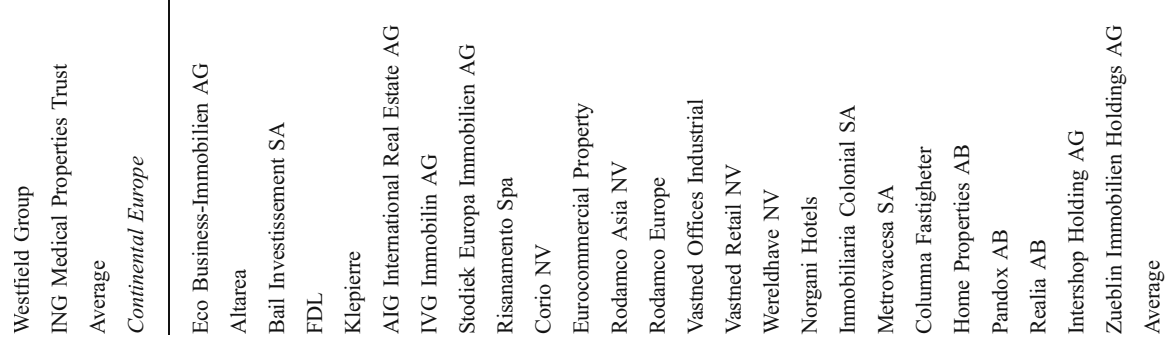




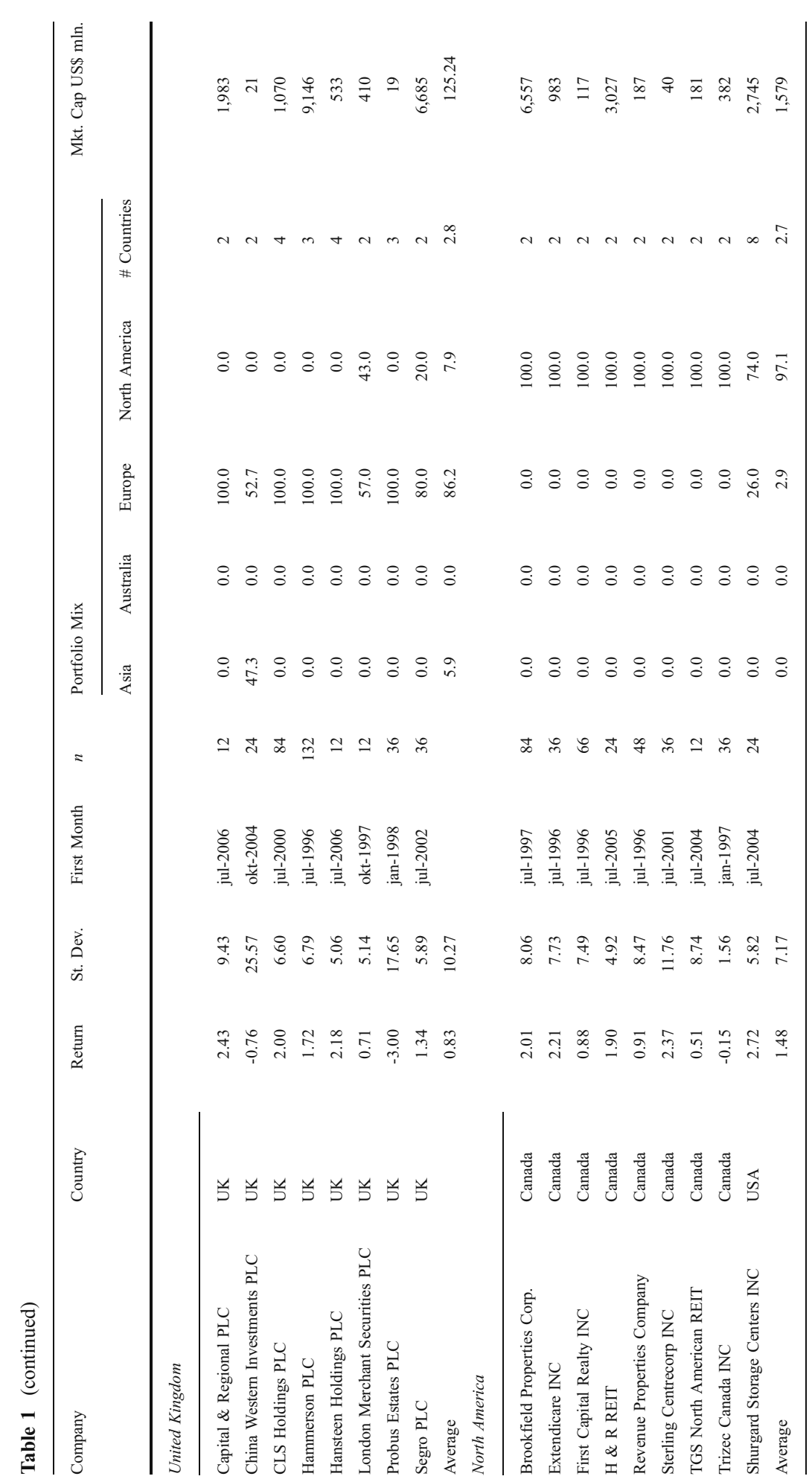


where $C I_{i, t}$ refers to the country index for country $i$ in month $t, R_{j, t}$ is the total return of the local company $j$ in month $t, C A P_{j, t}$ refers to the market capitalization of local company $j$ in month $t, n t$ is total number of companies that are local in country $i$ in month $t$ and $C I_{i, t=0}$ is 100 . Based on the returns of the country indices, we derive the customized benchmark for each international property company. We weigh the individual country allocations to mimic the country allocation of that particular international. We create a customized benchmark for each international company $k$ as follows:

$$
C B_{k, t}=C B_{k, t-1} *\left[1+\sum_{i=0}^{i=n k}\left(w_{k, t} * R_{i, t}\right)\right]
$$

where $C B_{k, t}$ is the customized benchmark for the international company $k$ in month $t$, $w_{k, t}$ represents the percentage invested in country $i$ in month $t$ by the international $k$, $R_{i, t}$ is the return of the country index of country $i, n k$ the total number of countries in which the international $k$ has invested in month $t$.

Figure 1 presents the value-weighted index consisting of the international property companies, the value-weighted index consisting of local property companies, and the market-weighted customized benchmark of the international companies. All indices are set at 100 in June 1996 and track the performance until the end of June 2007. ${ }^{5}$ The graph suggests that, over this eleven year period, local property companies have outperformed their international counterparts. While the internationals index increases from 100 in 1995 to 449 at the end of June 2007, the locals index increases from 100 to 515 over the same period. These increases correspond to average annual returns of $13.7 \%$ and $15.8 \%$, respectively. This difference may first of all be due to an information effect hindering performance of internationals, but it is important to note that the performance difference can also be partially attributed to an allocation effect, as the composition of the locals index may differ from the geographical asset allocation of international property companies.

The customized benchmark addresses this allocation effect by mimicking the portfolio composition of international property companies. However, internationals still underperform relative to the customized benchmark, with an annual performance difference of $2.7 \%$. This corresponds exactly with the $2.7 \%$ documented earlier by Eichholtz et al. (2001), over the period from 1984 through 1995. The performance difference between internationals and the customized benchmark is larger than the performance difference between internationals and the locals index. This may be due to the bias of internationals towards American and European property markets. Since Asian property companies underperformed in the early part of the sample, this allocation effect compensates some of the information effect.

These first descriptives suggest that international diversification remains costly in the global property market, even though markets have become more financially integrated.

\footnotetext{
${ }^{5}$ Although the sample period ranges from January 1996 to December 2007, this graph focuses on the period from June 1996 to June 2007. The half-year periods at the beginning and end of the sample period are excluded because of the limited availability of data for a number of international property companies during these periods.
} 


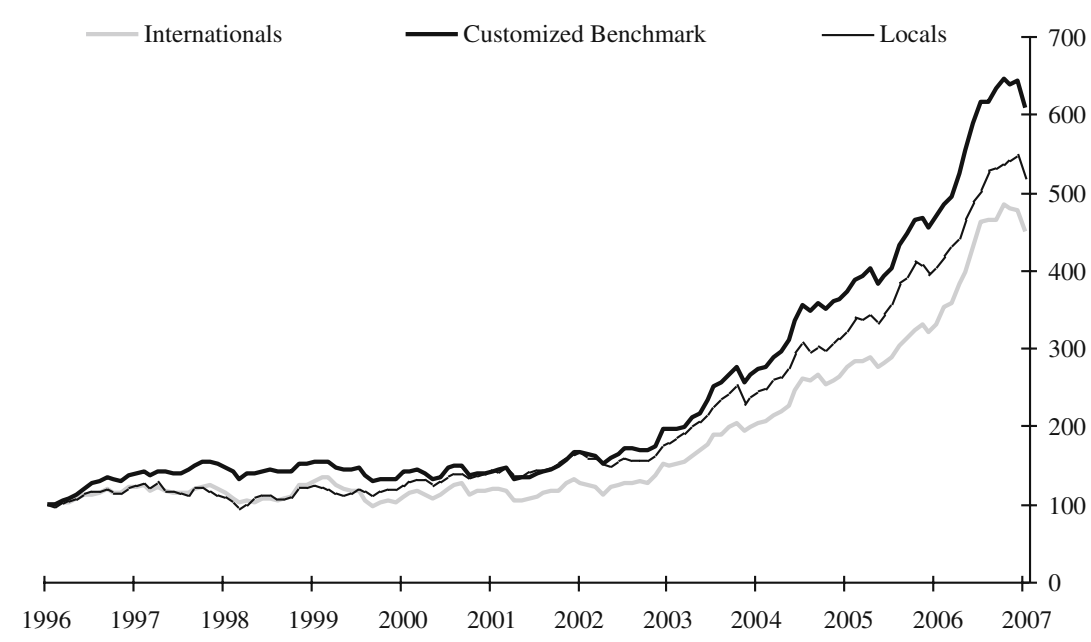

Notes: Figure 1 shows the performance of the internationals index, a locals index, and the customized synthetic benchmark. The locals index is a value-weighted index of the global universe of domestic property companies. The customized benchmark represents the summation of all mimicking benchmarks, which are weighted according to geographical asset allocation of the respective internationals.

Fig. 1 International Property Companies versus Benchmarks 1999-2007

To further assess whether the return differences between locals and internationals are indeed an indication for the costs of direct investments in foreign property markets, we investigate the volatility of the three return series and estimate risk-adjusted returns. To check the consistency of the performance difference between internationals and locals over time, we study both the full sample period and the three sub-periods. Panel A of Table 2 provides the descriptive statistics for the return indices. The table shows that the lower returns of the international companies relative to the local index and the customized benchmark are accompanied by a slightly higher level of risk. The annualized standard deviation of the internationals, locals and customized benchmark return series are $14.8 \%, 13 \%$ and $12.8 \%$, respectively. This translates into the highest Sharpe ratio for the mimicking index.

The results for the sub-periods show that, contrasting to Eichholtz et al. (2001), the superior performance of locals is not consistent over time. While internationals underperformed the customized benchmark by an annualized $7.7 \%$ in the first period, their performance in the second and third sub-period is rather similar to the stock returns of locals. Relative to the customized index, international property companies even outperform in the second period. This is also reflected in the Sharpe ratio of internationals, which is considerably lower for internationals than for locals in the first period, whereas in the second and third period they are at a comparable level.

The Sharpe ratio measures the excess return over the risk free rate per unit of total risk, but to evaluate an international's performance relative to the locals index or the customized benchmark, we estimate the Jensen's alpha as a risk-adjusted performance measure. This enables us to first determine the out- or underperformance of an 


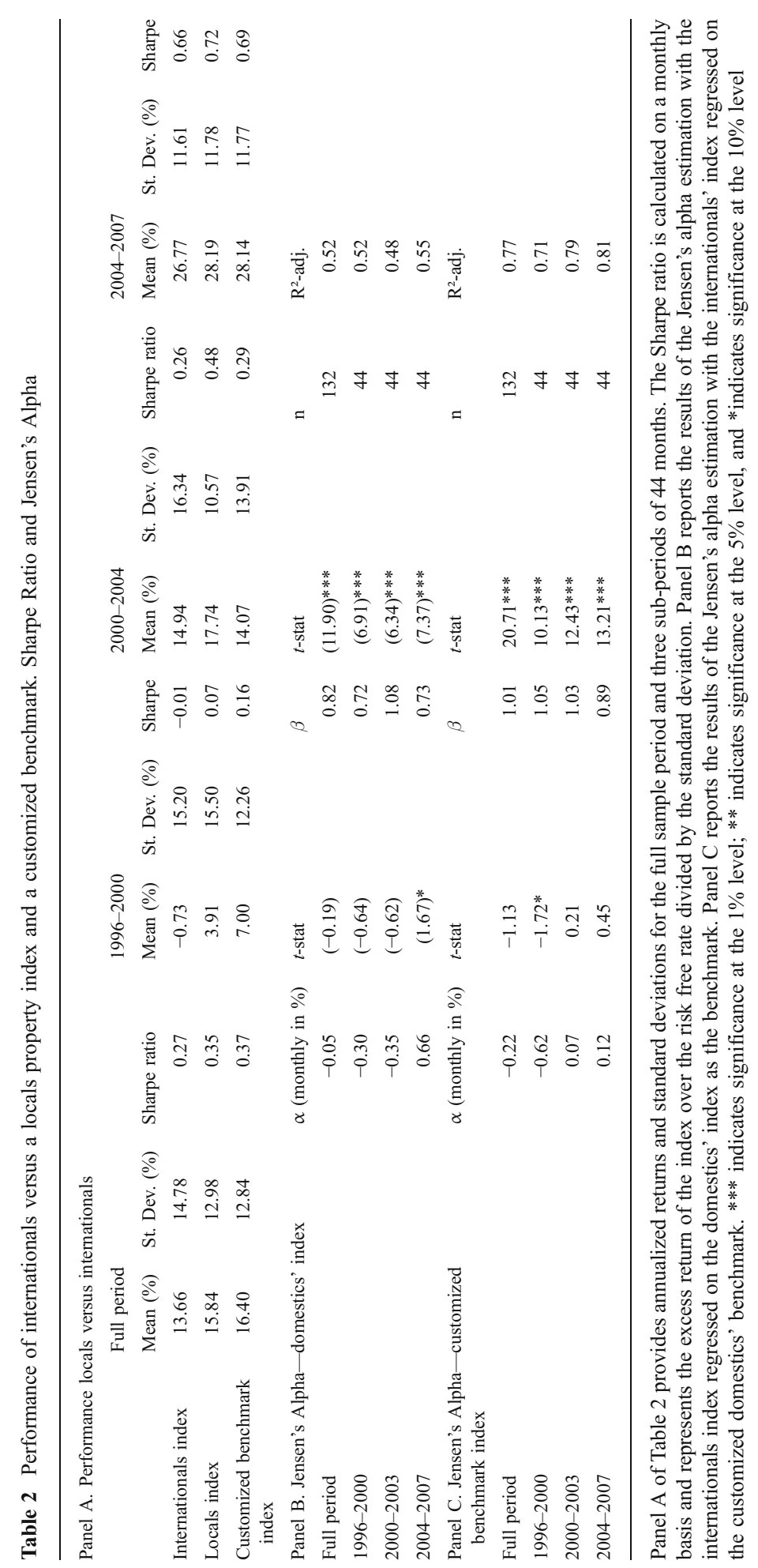


international property company relative to local property companies and thus to eliminate any effects of an international's country allocation decision.

$$
R_{k t}-R_{f t}=\alpha_{k}+\beta_{k}\left(R_{B t}-R_{f t}\right)+\varepsilon_{k t}
$$

where $R_{k t}$ is the return of the international property company $k$ at time $t, R_{f t}$ is the risk free rate, $R_{B t}$ the return of the locals index or the customized benchmark, and $\varepsilon_{k t}$ the error term. All returns are denominated in US\$, the 1-month U.S. T-bill rate serves as a proxy for $R_{f t}$.

Panel B of Table 2 provides the results of Eq. (3), using the locals index as the benchmark. Though statistically insignificant, alphas are consistently negative in both the full period and the first two periods of the sample. However, international property companies significantly outperform locally-oriented property companies by an annualized $8 \%$ in the third period.

Panel C shows the results of Eq. (3), estimated with the customized benchmark to control for allocation effects. For the full sample period, the alpha of $-0.22 \%$ suggests that internationals also underperformed when adjusting for geographical exposure. However, this result is not statistically significant. The estimated alphas of the internationals index in the three sub-periods show that it is mainly the first part of the sample period that drives the results. From 1996 to 2000, internationals show an annualized risk-adjusted underperformance of $7.5 \%$. This underperformance disappears in the latter part of the sample period, and even becomes positivethough not statistically significant.

Finally, to provide an insight into the development of internationals' relative performance over time, we estimate Jensen's alpha for each international company on an annual basis, based on the performance relative to the customized benchmark. The resulting mean and median alphas for the individual years are presented in Fig. 2. This graph also indicates that the performance of international companies relative to locals has improved over time. While the mean and median alphas are generally negative in the early years, they increase and even become positive in later years. ${ }^{6}$

\section{Performance Drivers}

It has been documented that performance differences between property companies that invest internationally and property companies that focus on their local market may be explained by a size effect: larger internationals tend to perform relatively well, possibly because of scale advantages relating to market information (Eichholtz et al. 2001). In addition, we hypothesize that the performance of internationals may be affected by: 1) political risk, 2) macroeconomic and market factors, and 3) company-specific factors.

We expect that a vicious political environment in the target countries is negatively related to the relative performance of internationals, as this may increase investment risk and decrease operating efficiency (La Porta et al. 2000b, 2002). With respect to macroeconomic and market factors, we expect that economic integration between

\footnotetext{
${ }^{6}$ We note that these results have to be interpreted with caution, given that the alpha estimates are based on annual periods.
} 


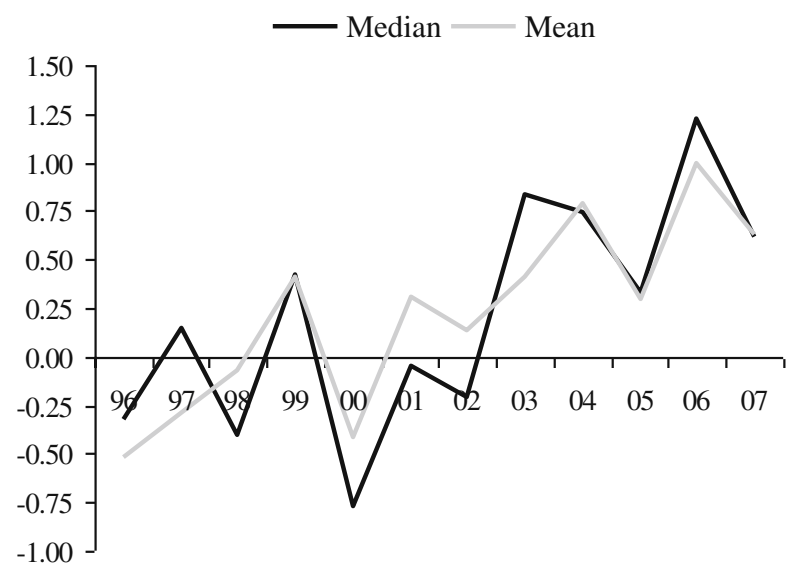

Notes: Figure 2 shows the mean and median performance of the international property companies relative to their domestic mimicking indices as measured by the monthly Jensen's alpha. The Jensen's alpha has been estimated over a 12 month period.

Fig. 2 Individual Alphas of International Property Companies 1996-2007

countries levels the playing field for international investors. Consequently, internationals investing in markets that are economically integrated with their home market may have higher alphas. In addition, differences in the risk-adjusted returns between internationals and locals are potentially larger in opaque and less liquid property markets. Regarding firm-specific factors, larger companies potentially benefit from economies of scale, reducing the information costs in foreign markets and leading to a higher alpha. Also, the extent to which international property companies are geographically diversified might influence performance (Boer et al. 2005).

To assess the political environment of different countries, we use the Index of Economic Freedom (IEF) published by the Heritage Foundation and The Wall Street Journal. This index provides a measure on the level of economic freedom in countries around the world and consists of ten sub-indices. We select the subindices "investment freedom", "property rights", and "freedom from corruption". Investment freedom examines a country's policies toward foreign investment and measures whether the government treats foreign companies similar to local companies. The property rights index reflects to what extent a country's laws protect private property rights and also assesses the risk of expropriation. The corruption index serves as a general indicator for the strength of a country's legal framework (Shleifer and Vishny 1993).

To construct a variable that reflects the political environment facing international property companies, we combine the three indices into a single variable by taking the equally weighted average of all three values in a given year and for a given country. ${ }^{7}$ Second, reported IEF scores are relative to the complete list of 165 countries covered by this index, of which our sample of 36 countries is a subset. We

\footnotetext{
${ }^{7}$ In 2007, correlations between investment freedom, property rights and freedom from corruption for the sampled countries range between $77 \%$ and $95 \%$.
} 
therefore calculate standardized values for the 36 countries in our sample for each individual year. Third, we calculate a political risk index $(P R I)$ for every international company. The $P R I$ is the average political risk of the foreign markets that the international invests in during the period it is considered to be an international:

$$
P R I_{k}=\frac{1}{y t} \sum_{y=0}^{y=y t}\left(\sum_{i=0}^{i=n k} w_{i, y, k} * z_{i, y}\right)
$$

where $y t$ refers to the total number of years the company $k$ is considered to be international, $n k$ is the total number of countries in which the company $k$ has invested in year $y, w_{i, y, k}$ refers to the proportion of foreign investment that company $k$ allocates to country $i$ in year $y$ and $z_{i, y}$ refers to the standardized freedom score for country $i$ in year $y$.

We measure the integration of financial markets by assessing the correlations between national markets. To this end, we construct a variable that measures the correlation between an international's local market and the foreign markets that an international invests in. For the former, the general market index of the international company's home market is used. The latter is represented by an index consisting of the country indices of the foreign markets that the company invests in. These country indices are weighted by the proportion of investments that the company allocates to the individual countries. The weights are adjusted annually to reflect changes in the company's country allocation. In a final step, the correlation (CORREL) between the local and foreign markets is calculated over the period when the company is considered to be international.

As a proxy for transparency of local property markets, we use the Real Estate Transparency Index, published by Jones Lang LaSalle (JLL). This measure is strongly correlated with liquidity. ${ }^{8}$ The Real Estate Transparency Index is based on a structured survey which addresses five key attributes of real estate transparency: availability of investment performance indices, availability of market fundamentals data, financial disclosure and governance among listed vehicles, regulatory and legal factors, and professional and ethnical standards. Based on these attributes, JLL assigns transparency scores to individual countries ranging from 1 to 5 , with 1 representing the highest level of transparency. We construct customized transparency indices $(T I)$ for each international company. The $T I$ reflects the average transparency of the foreign markets that an international invests in over the period when it is considered as international:

$$
T I_{k}=\frac{1}{y t} \sum_{y=0}^{y=y t}\left(\sum_{i=0}^{i=n k} w_{i, y, k} z_{i, y}\right)
$$

where $y t$ refers to the total number of years the company $k$ is considered to be international, $n k$ is the total number of countries in which the company $k$ has invested in year $y, w_{i, y, k}$ refers to the proportion of foreign investment that company $k$

\footnotetext{
${ }^{8}$ JLL (2008) show that liquidity - as measured by the share of global transaction volume relative to the share of GDP - is highly correlated with transparency across countries. Including both liquidity and transparency in the cross-sectional analysis would therefore also result in multicollinearity.
} 
allocates to country $i$ in year $y$ and $z_{i, y}$ refers to the standardized transparency score for country $i$ in year $y$.

To take firm-specific performance drivers into account, we include three variables. First, following Eichholtz et al. (2001), we include company size, proxied by the natural logarithm of the average monthly market capitalization of a company during the period it was international.

Second, we include geographical focus, proxied by the Herfindahl index, to measure the extent to which a company is truly diversified (Boer et al. 2005; Capozza and Seguin 1999):

$$
H I_{k}=\frac{1}{y t} \sum_{y=0}^{y=y t}\left(\sum_{i=0}^{i=n k}\left(w_{k, y}\right)^{2}\right)
$$

where $H I_{k}$ is the average geographical Herfindahl index for company $k, y t$ refers to the total number of years company $k$ is considered to be international, $n k$ is the total number of countries in which company $k$ has invested in year $y$ and $w_{k, y}$ represents the percentage invested in country $i$ in year $y$ by company $k$. The average Herfindahl index for the individual property companies may range from $1 / \mathrm{n}$ to 1 , where 1 represents a company that is focused on one country alone and values close to 0 indicate a high level of geographical diversification.

Third, we include a dummy variable taking the value of 1 if an international property company also invests outside its own continent.

To address the impact of firm- and market-specific variables on the risk-adjusted performance of internationals, we run the following equations:

$$
\begin{aligned}
& \alpha_{i}=\gamma_{0}+\gamma_{1} \text { PRI }_{i}+\gamma_{2} \text { CORREL }_{i}+\gamma_{3} \text { SIZE }_{i}+\gamma_{4} H I_{i}+\gamma_{5} \text { DIST }_{i}+\varepsilon_{i} \\
& \alpha_{i}=\theta_{0}+\theta_{1} T_{i}+\theta_{2} \text { CORREL }_{i}+\theta_{3} \text { SIZE }_{i}+\theta_{4} H I_{i}+\theta_{5} \text { DIST }_{i}+\eta_{i}
\end{aligned}
$$

where $\alpha_{i}$ refers to Jensen's alpha for company $i$, as estimated using Eq. (3), $P R I_{i}$ to the political environment, $T I_{i}$ to the real estate market transparency, CORREL $L_{i}$ to the level of economic integration, $S I Z E_{i}$ to the average market capitalization of the international company, $H I_{i}$ is a measure of geographical focus, $D I S T_{i}$ is a dummy variable taking the value of 1 if company $i$ also invests across continents, and $\varepsilon_{\mathrm{i}}$ and $\eta_{\mathrm{i}}$ are the error terms. ${ }^{9}$

Table 3 shows the regression results of Eqs. (7a) and (7b) for the 46 international property companies that have at last 24 monthly data-points. Panel A presents the results for the full sample period. Only the size coefficient is statistically significant and positively related to relative performance. This indicates that larger companies are indeed able to overcome informational disadvantages by growing in size, which is in line with Eichholtz et al. (2001). Other studies have also indicated that there is a scale effect in real estate investing, with an inverse relationship between equity betas and firm size (Ambrose et al. 2005; Yang 2001). The political environment, the level of economic integration, the transparency of the real estate market, the geographical focus and the measure of distance to the local market are not able to explain the

\footnotetext{
${ }^{9}$ Only companies with more than 24 monthly data-points are included to minimize noise and to ensure the accuracy of the estimates.
} 
Table 3 Explaining Jensen's Alpha, regression results

\begin{tabular}{|c|c|c|c|c|}
\hline & \multicolumn{2}{|c|}{ Equation (7a) } & \multicolumn{2}{|c|}{ Equation (7b) } \\
\hline \multicolumn{5}{|c|}{ Panel A. Full period: 01/1996-12/2007 } \\
\hline Political risk index & -0.19 & -0.63 & - & \\
\hline Transparency index & - & & 0.18 & 0.50 \\
\hline Economic market integration & -0.93 & -0.71 & -1.10 & -0.85 \\
\hline Company size in $\log$ & 0.24 & $2.38^{* *}$ & 0.23 & $2.24 * *$ \\
\hline Geographic Herfindahl index & -1.41 & -0.92 & -2.14 & -1.28 \\
\hline Distance & 0.29 & 0.83 & 0.32 & 0.91 \\
\hline Intercept & -0.32 & -0.30 & -0.08 & -0.08 \\
\hline$n$ & 46 & & 46 & \\
\hline $\mathrm{R}^{2}$ adj. & 0.08 & & 0.07 & \\
\hline \multicolumn{5}{|c|}{ Panel B. Sub-period: 01/1996-06/2001 } \\
\hline Political risk index & 0.44 & 1.64 & - & \\
\hline Transparency index & - & & 0.50 & $2.04 *$ \\
\hline Economic market integration & 1.96 & $1.83 *$ & 1.95 & $1.92 *$ \\
\hline Company Size in log & 0.29 & $2.80^{* *}$ & 0.31 & $3.21 * * *$ \\
\hline Geographic Herfindahl index & 0.23 & 0.15 & -0.47 & -0.29 \\
\hline Distance & 0.96 & $3.32 * * *$ & 0.74 & $2.81 * *$ \\
\hline Intercept & -3.63 & $-4.76 * * *$ & -3.51 & $-4.76^{* * *}$ \\
\hline$n$ & 23 & & 23 & \\
\hline $\mathrm{R}^{2}$ adj. & 0.59 & & 0.62 & \\
\hline \multicolumn{5}{|c|}{ Panel C. Sub-period: 07/2001-12/2007 } \\
\hline Political risk index & -0.15 & -0.38 & - & \\
\hline Transparency index & - & & 0.00 & 0.00 \\
\hline Economic market integration & -2.45 & -1.25 & -2.62 & -1.36 \\
\hline Company size in log & 0.06 & 0.40 & 0.05 & 0.36 \\
\hline Geographic Herfindahl index & -1.58 & -0.75 & -1.83 & -0.82 \\
\hline Distance & -0.24 & -0.45 & -0.25 & -0.48 \\
\hline Intercept & 2.28 & 1.31 & 2.46 & 1.44 \\
\hline$n$ & 40 & & 40 & \\
\hline $\mathrm{R}^{2}$ adj. & 0.07 & & 0.08 & \\
\hline
\end{tabular}

Table 3 reports the results of the OLS regressions on Eqs. (7a) and (7b). The political risk index is based on the Index of Economic Freedom (IEF), the measure of economic market integration is proxied by the correlation between the domestic and foreign markets invested in, the transparency of the property market is measured by the Real Estate Transparency Index of Jones Lang LaSalle, company size is represented by the natural logarithm of market capitalization, geographical focus is measured by the Herfindahl Index and distance is a binary dummy that takes the value of 1 if the company invests across continents. White's (1980) heteroskedasticity robust $t$-statistics within parentheses. $* * *$ indicates significance at the $1 \%$ level; ** indicates significance at the $5 \%$ level, and * indicates significance at the $10 \%$ level

cross-sectional variation in alpha. The adjusted $\mathrm{R}^{2} \mathrm{~s}$ of the two regressions are 0.08 and 0.07 , respectively.

A possible explanation for the poor explanatory power of models (7a) and (7b) is the time variation in the performance of internationals. Figure 2 indicated that the 
relative performance of internationals has substantially improved over the sample period. To further address this issue, we split the sample in two sub-periods of equal length. The cut-off date is June 2001. ${ }^{10}$

The estimated individual alphas for the two sub-periods are not reported here, but they provide further evidence that the costs of direct investments in foreign real estate have decreased over time. While in the first 6 years of the sample period the average alpha was $-0.33 \%$, it increased to $0.57 \%$ in the second sub-period. The difference in means is statistically different from zero. The fraction of alphas that is negative decreases from $78.3 \%$ in the first sub-period to $25 \%$ in the second sub-period.

Panel B of Table 3 presents the OLS results for the sub-period from 1996 through June 2001. In this period the explanatory power of the model is substantially stronger, with adjusted $\mathrm{R}^{2} \mathrm{~s}$ of 0.59 and 0.62 . Political risk $(P R I)$, which represents the riskiness of the political environment, has a positive though statistically insignificant coefficient. In line with the sign on the PRI coefficient, real estate market transparency $(T I)$ is positively and significantly related to the performance of internationals. In terms of economic significance, the coefficient of 0.50 implies that investing in markets with a transparency score that is one standard deviation higher, leads to an annual increase in alpha of $6.0 \%$. This evidence is in line with Liao and Mei (1999) who study the effect of institutional factors on real estate returns. In a more general framework, La Porta et al. (2002) find that firms investing in more transparent countries with a strong institutional framework outperform firms in less transparent markets.

This implies that there is at least some evidence that the disadvantages faced by foreign property investors are lower in countries with strong political and market institutions. The fact that market transparency seems to be more important than political risk suggests that access to information plays a distinguishing role in the relative performance of international property investors.

With respect to the influence of firm-specific factors on internationals' returns, firm size (SIZE) has a significantly positive impact on the relative performance of an international in the first sub-period. The extent to which a property company is a true international investor does not matter for performance, as indicated by the insignificant coefficients on the Herfindahl index. This contrasts existing evidence regarding international diversification, which has been shown to be value-destroying in continental Europe (Boer et al. 2005). However, international property companies that are active across continents rather than diversifying within their own region perform significantly better than those that stay within their continent. The difference in annualized alphas amounts to about $11.5 \%$ and $8.9 \%$ in Eqs. $7 \mathrm{a}$ and $7 \mathrm{~b}$, respectively. This confirms the presence of a "continental factor" in real estate returns $^{11}$ and may indicate that there is still a disconnect in economic drivers

\footnotetext{
${ }^{10}$ Using the same three sub-periods as in Table 2, Panel B, is not optimal as the alphas are estimated over shorter periods, which increases the noise of the estimations. Moreover, several firms would be excluded due to an insufficient number of monthly data points.

11 There has been an extensive discussion on the presence of local, regional, continental and global factors in the literature. See for example Bond et al. (2003), Eichholtz et al. (1998), Hamelink and Hoesli (2004) and Ling and Naranjo (2002).
} 
between different continents - although the recent contagion in financial markets would suggest otherwise.

The results of the analysis for the second sub-period are substantially different. Panel $\mathrm{C}$ of Table 3 shows that models (7a) and (7b) have lost most of their explanatory power, and the six independent variables no longer have a significant impact on the risk-adjusted performance of international property companies. This may be due to the limited cross-sectional variability of the alphas, as internationals do not underperform locals in the second half of the sample period. The results may also imply that investors in internationally oriented property companies now take country risk into account in their investment decisions - the risk is priced. Last, and most important, the results for the latter half of the sample period may be an indication for the increased international convergence in terms of market transparency. With less variation in the opacity of real estate markets, the economic implications of differences between countries in their ranking on the Political Risk Index or the JLL Transparency Index are limited for property investors.

\section{Conclusions and Discussion}

This paper compares the performance of internationally operating property companies with property companies focusing on their local market, for the period from 1996 through 2007, shedding light on the importance of political and market institutions for the performance of international property investors. The results show that international property companies only underperform their local peers in the early years of the sample period, while the underperformance disappears in the later years. We show that the underperformance in the early years is driven by the institutional environment, the level of economic integration, and the real estate market transparency of the countries that the international companies invest in. Furthermore, the results show that larger international companies and those companies that also invest outside their continent perform significantly better. In the later years of the sample period there are no more signs of underperformance, and all factors lose their ability to explain performance differences among international property companies.

For end-investors that want to build up exposure to foreign real estate, these results imply that that they could either buy shares of internationally diversified property companies or hold a portfolio of foreign property companies that focus on their home market. Neither of those two strategies is superior given that differences in the returns have disappeared over the last years.

These results support the increase in cross-border investment activity by listed property companies observed in recent years. Given that the costs associated with direct investments in cross-border real estate have decreased, property companies may well adopt a global investment strategy. However, managers of property companies should learn from the results in the early years in our sample period. The analysis shows that foreigners may be at a disadvantage especially in countries with an unfavorable political environment, an opaque real estate market, and a low level of economic integration. The companies in our sample mainly invest in countries that have relatively high scores on these dimensions, and moreover, transparency scores have improved over the sample period. In less mature markets, such as 
Eastern Europe, Turkey and some emerging countries in Asia, the costs of crossborder investments may still be significant. This is relevant, as listed property companies and other property investors have now ventured into these countries. Consequently, managers should carefully evaluate the investment environment before entering new markets.

An important limitation of this paper is that the sample size remains relatively small, especially in the early years that we analyze. This may hamper the generalization of the results and the ability to test more elaborate performance attribution models. Given that the availability of information and data on international property markets gradually increases, future research regarding the costs of international property investment may take the results of this study as a starting point.

Open Access This article is distributed under the terms of the Creative Commons Attribution Noncommercial License which permits any noncommercial use, distribution, and reproduction in any medium, provided the original author(s) and source are credited.

\section{References}

Adler, M., \& Dumas, B. (1975). Optimal international acquisitions. Journal of Finance, 30, 1-19.

Ambrose, B. W., Highfield, M. J., \& Linneman, P. D. (2005). Real estate and economies of scale: The case of REITs. Real Estate Economics, 33, 323-350.

Armstrong, V., \& Riddick, L. (1998). Evidence that differences in bankruptcy law among countries affect firm returns. Working Paper: Washington State University.

Boer, D., Brounen, D., \& Op't Veld, H. (2005). Corporate focus and stock performance: International evidence from listed property markets. Journal of Real Estate Finance and Economics, 31, 263-281.

Bond, S. A., Karolyi, G. A, \& Sanders, A. B. (2003). International real estate returns: A multifactor, multicountry approach. Real Estate Economics, 31, 481-500.

Capozza, D. R., \& Seguin, P. J. (1999). Focus, transparency and value: The REIT evidence. Real Estate Economics, 27, 587-619.

Conover, C. M., Friday, H. S., \& Sirmans, C. F. (2002). Diversification benefits from foreign real estate investments. Journal of Real Estate Portfolio Management, 8, 17-25.

Dahlquist, M., Pinkowitz, L., \& Stulz, R. M. (2003). Corporate governance and the home bias. Journal of Financial \& Quantitative Analysis, 38, 87-110.

Dhar, R., \& Goetzmann, W. N. (2006). Institutional perspectives on real estate investing: The role of risk and uncertainty. Journal of Portfolio Management, 32, 106-116.

Edelstein, R., Qian, W., \& Tsang, D. (2009). How do institutional factors affect international real estate returns? Working Paper: UC Berkeley.

Eichholtz, P. M. A. (1996). Does international diversification work better for real estate than for stocks and bonds. Financial Analyst Journal, 52, 56-62.

Eichholtz, P. M. A. (1997). How to invest internationally: Region and property type on a global scale. Real Estate Finance, 14, 51-56.

Eichholtz, P. M. A., \& Kok, N. (2007). The EU Reit and the internal market for real estate. Brussels: European Property Federation.

Eichholtz, P. M. A., Huisman, R., Koedijk, K., \& Schuin, L. (1998). Continental factors in international real estate returns. Real Estate Economics, 26, 493-509.

Eichholtz, P. M. A., Koedijk, K., \& Schweitzer, M. (2001). Global property investment and the costs of international diversification. Journal of International Money \& Finance, 20, 349-366.

Geurts, T. G., \& Jaffe, A. J. (1996). Risk and real estate investment: An international perspective. Journal of Real Estate Research, 11, 117-130.

Goetzmann, W. N., \& Wachter, S. M. (1995). The global real estate crash: Evidence from an international database. Singapore: AREUEA International Congress on Real Estate.

Hamelink, F., \& Hoesli, M. (2004). What factors determine international real estate security returns? Real Estate Economics, 32, 437-462. 
Hobbs, P., Chin, H., \& Topintzi, E. (2007). Global real estate investment and performance. London: RREEF Research.

Hoesli, M., Lekander, J., \& Witkiewicz, W. (2004). International evidence on real estate as a portfolio diversifier. Journal of Real Estate Research, 26, 161-206.

Jones Lang LaSalle (JLL). (2008). From opacity to transparency: Real estate transparecny index. London: Jones Lang LaSalle.

La Porta, R., Lopez-De-Silanes, F., Shleifer, A., \& Vishny, R. (1998). Law and finance. Journal of Political Economy, 106, 1113-1155.

La Porta, R., Lopez-De-Silanes, F., Shleifer, A., \& Vishny, R. (2000). Agency problems and dividend policies around the world. Journal of Finance, 55, 1-33.

La Porta, R., Shleifer, A., Lopez-De-Silanes, F., \& Vishny, R. W. (2000). Investor protection and corporate governance. Journal of Financial Economics, 58, 3-27.

La Porta, R., Lopez-De-Silanes, F., Shleifer, A., \& Vishny, R. (2002). Investor protection and corporate valuation. Journal of Finance, 57, 1113-1155.

Liao, H., \& Mei, J. P. (1999). Institutional factors and real estate. International Real Estate Review, 2, 21-34.

Ling, D. C., \& Naranjo, A. (2002). Commercial real estate return performance: A cross-country analysis. Journal of Real Estate Finance \& Economics, 24, 119-142.

Liu, C. H., \& Mei, J. P. (1998). The predictability of international real estate markets, exchange risks and diversification consequences. Real Estate Economics, 26, 3-40.

Newell, G., \& Worzala, E. (1995). The role of international property in investment portfolios. Journal of Property Finance, 6, 55-63.

Newell, G., \& Worzala, E. (1997). International real estate: A review of strategic investment issues. Journal of Real Estate Portfolio Management, 3, 87-96.

Quan, D. C., \& Titman, S. (1997). Commercial real estate prices and stock market returns: An international analysis. Financial Analysts Journal, 53, 21-34.

Shleifer, A., \& Vishny, R. W. (1993). Corruption. Quarterly Journal of Economics, 108, 599-617.

White, H. (1980). A heteroskedasticity-consistent covariance matrix estimator and a direct test for heteroskedasticity. Econometrica, 48, 817-838.

Worzala, E. (1994). Overseas property investments: How are they perceived by the institutional investor? Journal of Property Valuation and Investment, 12, 119-141.

Worzala, E., \& Sirmans, C. F. (2003a). International direct real estate investment: A review of the literature. Urban Studies, 40, 1081-1114.

Worzala, E., \& Sirmans, C. F. (2003b). Investing in international real estate stocks: A review of the literature. Urban Studies, 40, 1115-1149.

Yang, S. (2001). Is bigger better? A re-examination of the scale economies of Reits. Journal of Real Estate Portfolio Management, 7, 67-77.

Ziobrowski, A., \& Curcio, R. (1991). Diversification benefits of us real estate to foreign investors. Journal of Real Estate Research, 6, 119-142. 